\title{
Evaluation of Genetic Diversity in Some Banana Hybrids using ISSR Markers
}

\author{
Sukhen Chandra Das ${ }^{1 *}$, T.N. Balamohan ${ }^{2}$, K. Poornima ${ }^{3}$ and I. Van Den Bergh ${ }^{4}$ \\ ${ }^{1}$ Horticulture, College of Agriculture, Tripura, India \\ ${ }^{2}$ Department of Fruit Crop, HC and RI, TNAU, Tamil Nadu, India \\ ${ }^{3}$ Nematology, Department of Nematology, HC and RI, TNAU, Tamil Nadu, India \\ ${ }^{4}$ International Network for the Improvement of Banana and Plantain-Asia and the Pacific, c/o \\ IRRI Khush Hall, Los Banos, Laguna 4031, Philippines \\ *Corresponding author
}

\section{A B S T R A C T}

\begin{tabular}{|l|}
\hline K e y w o r d s \\
Diversity, Hybrids, \\
Markers, Cluster \\
analysis, \\
Polymorphism, ISSR, \\
Dendrogram
\end{tabular}

\section{Keywords}

\section{Introduction}

Bananas and plantains belong to the family Musaceae and are cultivated throughout the humid tropics and sub-tropics. This crop is perennial with a faster relative growth rate compared to other fruit crops, while producing fruit all year round. Because of their nutritional value, bananas and plantains are considered the fourth most important crop worldwide after rice, wheat and corn. DNA marker technologies have been widely used in
Bananas (Musa spp.) are mostly diploid or triploid with various combinations of genomes inherited from their ancestors. Inter simple sequence repeat (ISSR) markers were used for evaluation of genetic diversity of some synthetic Banana Hybrids. A total of 10 primers were evaluated for banana hybrids based on ISSR polymorphism. Diversity analysis carried out by using ISSR markers in some Banana hybrids revealed the confirmation of the hybridization along with the phylogenetic relationship of the hybrids with their parents. Out of the 10 primers studied, six primers exhibited scorable markers. A total of 54 markers were produced. The markers ranged from 5 to 8 in different primers. Of the 54 markers produced, 30 were polymorphic which account to 53.83 per cent polymorphism. Among the six primers studied ISSR 812 (UBC-812) produced maximum number of olymorphic bands among the banana genotypes and might be useful for genetic diversity or DNA finger printing studies. 
Grapin et al., (1998) and Kaemmer et at.,(1997) and amplified fragment length polymorphism (AFLP) Loh et al., (2000) and Wong et al., (2001) Random Amplified Polymorphic DNA (RAPD) is a polymerase chain reaction (PCR) based technique which use random primers to generate DNA fragments which can be used as genetic markers, Williams et al.,(1990), Welsh and Mc Clelland, (1990), Howell, et al., (1994) and Pillay et al., (2000) is another such technique which allows one to easily back taxon names with a molecular identification system in the form of a barcode inherent to the plant. Using this technique, an unlimited number of polymorphic bands can be produced with relative ease form minute amounts of genomic DNA, Welsh and McClelland, (1990) allowing simultaneous screening of a large number of accessions. RAPD based fingerprinting has been successfully applied to the characterization of diverse Musa germplasms, Bhat and Jarret, (1995), Onguso et al., (2004), analysis of Musa breeding populations Crouch et al., (1999) and detection of somaclonal variants, Grajal Martin et al., (1998). Banana breeding programme in India was started as early as 1949 at aduthurai. Several South Indian bananas were found to be more closely related to $M$. bulbisiana than $M$. acuminate as revealed by the metroglyph, Raman et al., (1968). Bhakthavatsalu and Sathiamoorthy (1979) also elaborated upon the genomic status and breeding potential of many South Indian banana. As many synonyms exist for each clone and are differently name at various regions, much confusion prevails on the nomenclature of banana clones. In this situation, molecular characterization helps to identify clones unambiguously. In this context, banana breeding was initiated at Tamil Nadu Agricultural University, Coimbatore and many interdiploid crosses were attempted (Table 4). This had resulted in many diploids, triploids and tetraploids hybrids which were evaluated for their resistance against nematodes in both field and pot conditions. The hybrids were developed with male parent as resistant sources. These hybrids have to be confirmed for their hybridity taste and see the banding patterns of each and every hybrids, for which RAPD is an efficient way. ISSR analysis has been used to classify genotypes of Musa representing the AA, AAA, AAB and BBB genome, Howell et al., (1994). Molecular characterization of different clones of banana has been attempted by many authors in India. Jagannath et al., (2003) characterized many AA and AB diploids using RAPD markers. Rekha et al., 2004 made an attempt to study the variability between the $\mathrm{AB}$ cultivars. The evolved hybrids were subjected to diversity analysis to study the phylogenetic relation of the hybrids with their pedigree through ISSR markers. The main objective of the study is to evolve new synthetic hybrids by crossing the commercial triploids with improved resistant potential diploids.

\section{Materials and Methods}

The present study was taken up at the College orchard, Horticultural College and Research Institute, Tamil Nadu Agricultural University, Coimbatore during the period from 2005 to 2007, to evolve new banana hybrids for yield and quality combined with resistance to nematodes. The commercial cultivars and existing female fertile resistant hybrids were crossed with potential male donors (Pisang Lilin, Anaikomban, Rose and $\mathrm{H}$ 201) to evolve new hybrids as described in Table 3. Total of 7550 crosses were made with 63 different cross combinations, out of which 122 seedling have been generated and synthetic hybrids used for the experiment. The new hybrids evolved were planted in the main field for evaluation. The seedlings at twenty leaf stage were transplanted in the main field without trimming the roots since the corm was 
too small. The main field selected was highly infested with nematodes (more than two nematodes per gram of soil), so as to facilitate screening the hybrids for nematode resistance. Seven parents were used in the crosses are shown in the table 4, out of which male parents Pisang Lilin used as resistant cheek and Rasthali used for susceptible cheek in the present experiment.

\section{DNA extraction, quantification and quality cheek}

Fresh leaf samples (from unfurling leaves) of all the 18 genotypes (hybrids and parents) collected from the field were used for isolation of genomic DNA (Table 4). Isolation was done following the method of Gawel and Jarret (1991), with a slight modification. Mercaptoethanol (1\%) and Polyvinyl pyrrolidone (PVP) $0.2 \%$ were added to the extraction buffer to remove the phenolics. Leaf tissue $(0.5 \mathrm{~g})$ was ground with liquid nitrogen and to this powder $750 \mu \mathrm{l}$ of preheated $\mathrm{CTAB}$ buffer $\left(65^{\circ} \mathrm{C}\right)$ was added. It was then incubated at $65^{\circ} \mathrm{C}$ in a water bath for 1 hour. After bringing the tubes to room temperature, equal volume $(750 \mu \mathrm{l})$ of chloroform: isoamyl alcohol (24: 1) was added and the contents were mixed well for 10 minutes to form an emulsion.

It was then centrifuged at $10,000 \mathrm{rpm}$ for 15 minutes. The supernatant was transferred to a fresh tube and re-extracted with chloroform: isoamyl alcohol. The aqueous phase was transferred to a new tube and 2/3 rd volume of ice cold isopropanol was added and incubated in a freezer overnight. The contents were then centrifuged at $10,000 \mathrm{rpm}$ for 10 minutes at $4^{\circ} \mathrm{C}$. The pellet was washed with $70 \%$ ethanol and air dried. The crude DNA was purified by RNase $(10 \mathrm{mg} / \mathrm{ml})$ treatment followed by phenol: chloroform extraction. The DNA was ethanol precipitated and finally dissolved in TE buffer, pH-8.0, $(10 \mathrm{mM}$ Tris, $1 \mathrm{mM}$
EDTA). The DNA was quantified by a UVSpectrometer at $260 \mathrm{~nm}$, adjusted to the concentration of $100 \mathrm{ng} / \mu \mathrm{l}$, and stored at $-20^{\circ} \mathrm{C}$ in $25 \mu \mathrm{l}$ volumes until use. To check the quality and quantity of the extracted genome DNA, gel electrophoresis was carried out on 0.8 per cent agarose gel. DNA concentration for PCR amplification was estimated by comparing the band intensity of a sample with the band intensities of known dilutions that gave good amplifications. The dilutions were carried out by dissolving the genomic DNA in appropriate quantity of TE buffer ( $\mathrm{pH} \mathrm{8.0)}$ as postulated by Meenakshisundaram (2002).

\section{ISSR analysis}

DNA from the selected genotypes were used for ISSR analysis following the method recommended by Bhat and Jarret (1995) with require modification. A total of ten ISSR primers (as described by University of British Columbia, Canada) synthesized at Sigma Aldrich (USA), Bangalore, were used for amplifying the genomic DNA. Amplification was carried out in $15 \mu \mathrm{l}$ reactions containing 20- $30 \mathrm{ng}$ of genomic DNA, $1.5 \mu \mathrm{l}$ of $1.5 \mathrm{mM}$ of assay buffer, $0.75 \mu \mathrm{l}$ of $10.0 \mathrm{mM}$ of $\mathrm{d}$ NTPs, $1.2 \mu \mathrm{l}$ of $0.5 \mu \mathrm{M}$ of primer, $0.18 \mu 10.25$ $\mathrm{mM}$ of $\mathrm{MgCl}_{2}$ and $0.18 \mu \mathrm{l}$ of $3 \mathrm{U} / \mu 1 \mathrm{Taq}$ DNA polymerase (Bangalore Genei Pvt. Ltd., Bangalore) and $8.19 \mu \mathrm{l}$ of sterile water. Amplifications were performed in PTC Thermal Cycler (MJ Research Inc.,) programmed for an initial denaturation at $94^{\circ}$ $\mathrm{C}$ for $5 \mathrm{~min}$., 40 cycles of $1 \mathrm{~min}$ denaturation at $94^{\circ} \mathrm{C}, 1 \mathrm{~min}$ annealing at $41^{\circ} \mathrm{C}$ and $1 \mathrm{~min}$. extension at $72^{\circ} \mathrm{C}$ and a final extension of 5 minutes at $72^{\circ} \mathrm{C}$ and at $4^{\circ} \mathrm{C}$ for 30 minutes. PCR amplified products $(4 \mu \mathrm{l})$ were resolved in a $4 \%$ denaturing poly acrylamide gel by electrophoresis (PAGE) at 300 volts, $400 \mathrm{~mA}$ and 100 watts for 3.5 hours and viewed by silver staining, Panaud et al., (1996). Sizes of the identified bands were determined relative to a $1 \mathrm{~kb}$ ladder (MBI Fermentas, Germany). 


\section{Electrophorosis}

The ISSR-PCR products were separated in 1.5 per cent $(w / v)$ agarose gel in $1 \mathrm{x}$ TAE buffer (0.4M Tris, $0.2 \mathrm{M}$ acetic acid, $10 \mathrm{mM}$ EDTA, pH8.4) containing $0.5 \mu \mathrm{g} / \mathrm{ml}$ ethidium bromide (Sambrook et al., 1989). Along with the PCR amplified products, Lambda DNA (EcoRI and HindIII double digest) as standard marker were subjected to electrophoresis in 1.5 per cent agarose gel in $1 \mathrm{x}$ TBE buffer at $8 \mathrm{~V} /$ centimetre for $4-5$ hours. The electronic image of the ethidium bromide stained gel was visualized and documented in gel documentation system (Model Alpha imager 1200, Alpha Innotech Crop., USA). The 100bp DNA ladder was used as a size marker.

\section{Loading DNA and running the gel}

A piece of parafilm was placed on the solid surface and $1 \mu \mathrm{l}$ of genomic DNA $(25 \mathrm{ng} / \mu \mathrm{l})$ was pipetted on it. The contents were loaded into the wells carefully with the help of micropipette. Lambda DNA (Eco RI and Hind III double digest) used as the standard marker. The gel was run for 1-2 hours until the tracking dye reaches half of the gel and bands were visualized and documented in gel documentation system (Model Alpha imager $^{\mathrm{TM}}$ 1200, Alpha Innotech Corp., California, USA).

\section{Scoring and cluster analysis}

In ISSR only two states (' 1 ', present and ' 0 ', absent) can be distinguished at each band position. Each band position corresponds to a locus with two alleles, presence and absence of the band, respectively. Polymorphism was scored as presence or absence from distinct reproducible ISSR bands obtained from all 10 primers across all the 18 genotypes. The average polymorphism information content (PIC) and marker index (MI) were calculated by applying the formulas given by Powell et al., (1996) and Smith et al., (1997). The binary data matrices were entered into the NTSYS pC package (Exeter softwere, New york). The data were analysed using qualitative routine to generate Jaccard's Similarity construct a dendrogram using UPGMA (Unweighted pair Group Method with Arithmetic Average) and the SHAN (Sequential Heirarchial and Nested Clustering) routine in the NTSYS programme. Data analysis was done using NTSYSPC version 2.02 by Rohlf, (1994).

\section{Results and Discussion}

Result of DNA amplification showed that the 18 accession of banana hybrids and parents produced a wide array of strong and weak bands. However, only distinct, reproducible well-resolved fragments were scored as present or absent band for each of ISSR primers with 18 accessions. Figure 1 and 2 illustrated the typical level of polymorphisms observed among the 18 accession for primer UBC 812. Out of 10 primers used, six produced scorable markers. A total of 54 markers were produced. The markers ranged from 5 to 8 in different primers. The average number of markers / primer was 9 and 54 markers produced, 30 were polymorphic which account to 53.83 per cent polymorphism (Table 1,2 and 3). Cluster analysis was performed on Jaccard's similarity coefficient matrices calculated for ISSR markers to generate a dendrogram for 18 hybrids and parents. The similarity coefficients ranged from 0.31 to 1.00 . The dendrogram separated the 18 hybrids and parents into two major clusters (Table 5). The first cluster had only hybrid H 504. All the other hybrids and parents were grouped into one major cluster (Table 4, Fig. 3). Number of DNA amplification bands depended on how primer attached to its homolog at DNA template, Tingey et al., (1994). DNA fingerprinting has been carried out as a result 
of substantial achievements in marker isolation and protocol optimisation. Nevertheless, commercial imperatives demand that DNA fingerprinting accomplishes more than just technological advances. International consensus is being reached on general guidelines for employing DNA fingerprints as legal evidence. Advances in the technology to economise the procedure and international consensus in operational framework are critical to the future of DNA fingerprinting. Molecular markers are of more recent development, and possess many advantages which make them superior to morphological markers. Molecular markers can be used to directly examine the DNA in order to find polymorphisms in the sequence. This offers the possibility of finding large numbers of polymorphisms which are not subject to environmental influence. Each molecular marker technique varies from each other in the number of loci examined, dominance or codominance and ease of application.

DNA based marker techniques can supply additional information which are not available from the examination of morphological characteristics alone by Jarret and Gawel (1995). The Inter Simple Sequence Repeats (ISSR) are DNA-based marker techniques that has been successfully used to determine genetic diversity and relationships Musa germplasms Kaemmer et al., (1992), Howell et al., (1994), Bhat and Jarret (1995), Crouch et al., (2000), Jain et al., (2007), Racharak and Eidathong (2007), Ruangsuttapha et al., (2007), Agoreyo et al.,(2008), Brown et al.,(2009) and for genome identification, Howell et al., (1994), Pillay et al., (2000), analysis of Musa breeding populations, Crouch et al., (1999), detection of somaclonal variants, Grajal-Martin et al., (1998) and genetic stability, Harirah and Khalid (2006), Ray et al., (2006), Lakshmanan et al., (2007) and Venkatachalam et al.,(2007). Using these techniques an unlimited number of polymorphic bands can be produced with relative ease from minute amounts of genomic DNA, Welsh and McClelland(1990), Godwin et al., (1997), Reddy et al., (2002) allowing simultaneous screening of a large number of accessions. ISSR and RAPD were used in determinate genetic stability of three economically important banana (Musa spp.) cultivars and showed that ISSR detected more polymorphism than RAPD, Ray et al., (2006). Similarly, ISSR were used for detection of genetic uniformity of micropropagated plantlets, Rout et al., (2009) and for screening in vitro mutagenesis and variance Khatri et al., (2011). The study also reported the use of ISSR to assess the genetic diversity and classification of 27 wild banana accessions and showed that the collected germplasm was derived from diverse origins, Qin et al., (2014).

Table.1 Level of polymorphism detected by ISSR analysis banana hybrids and parents

\begin{tabular}{|c|l|c|}
\hline 1 & Genotypes screened & $\mathbf{1 8}$ \\
\hline 2 & Type of marker & ISSR \\
\hline 3 & Number of primers used & 6 \\
\hline 4 & Total number of markers & 54 \\
\hline 5 & Range of markers across primers & $5-18$ \\
\hline 6 & Average number of markers/primer & 9 \\
\hline 7 & Number of monomorphic markers & 24 \\
\hline 8 & Number of polymorphic markers & 30 \\
\hline 9 & Percentage polymorphism & 53.83 \\
\hline
\end{tabular}


Table.2 ISSR products generated by 6 primers for selected phase banana hybrids

\begin{tabular}{|l|c|c|c|}
\hline ISSR primer & Total markers & Polymorphic markers & Polymorphism \% \\
\hline ISSR 835 & 7 & 4 & 57.14 \\
\hline ISSR 834 & 11 & 4 & 36.36 \\
\hline ISSR 823 & 5 & 1 & 20.00 \\
\hline ISSR 812 & 6 & 6 & 100.00 \\
\hline ISSR 811 & 18 & 12 & 66.66 \\
\hline ISSR 808 & 7 & 3 & 42.85 \\
\hline
\end{tabular}

Table.3 List of primers used for ISSR analysis

\begin{tabular}{|c|l|l|c|}
\hline S.No & Primer Details & \multicolumn{1}{|c|}{ Sequence information (5' - 3') } & No.of bases \\
\hline 1. & UBC -808 & AGA GAG AGA GAG AGA GC & 17 \\
\hline 2. & UBC- 809 & AGA GAG AGA GAG AGA GG & 17 \\
\hline 3. & UBC- 811 & GAG AGA GAG AGA GAG AC & 17 \\
\hline 4. & UBC- 812 & GAG AGA GAG AGA GAG AA & 17 \\
\hline 5. & UBC- 823 & TCT CTC TCT CTC TCT CC & 18 \\
\hline 6. & UBC- 834 & AGA GAG AGA GAG AGA GYT* & 18 \\
\hline 7. & UBC- 835 & AGA GAG AGA GAG AGA GYC* & 18 \\
\hline 8. & UBC- 840 & GAG AGA GAG AGA GAG AYT* & 18 \\
\hline 9. & UBC- 841 & GAG AGA GAG AGA GAG AYC* & 18 \\
\hline 10. & UBC- 844 & CTC TCT CTC TCT CTC TRC* & \\
\hline
\end{tabular}

* Single letter abbreviations for mixed base positions

$\mathrm{R}=(\mathrm{A}, \mathrm{G}), \mathrm{Y}=(\mathrm{C}, \mathrm{T})$

Table.4 Details of banana hybrids and parents used in the present study

\begin{tabular}{|c|c|c|c|}
\hline S. No & Hybrids & Parentage & Genome \\
\hline 1 & H-504 & H-03-09 x PL & AAABB \\
\hline 2 & H-508 & ANK x PL & AA \\
\hline 3 & H-511 & $\mathrm{H}-02-34 \times \mathrm{Ykm} \# 5$ & $\mathrm{AABB}$ \\
\hline 4 & H-515 & Mano. x ANK & AAA \\
\hline 5 & H-516 & ANK x PL & AA \\
\hline 6 & H-531 & Poovan x PL & $\mathrm{AAB}$ \\
\hline 7 & H-532 & H-201 x Mano. & $\mathrm{AAB}$ \\
\hline 8 & H-534 & H-03-13 x Rose & $\mathrm{AAB}$ \\
\hline 9 & H-537 & $(\mathrm{H}-201 \times \mathrm{PK}) \times$ Rose & AABB \\
\hline 10 & H-540 & $(\mathrm{H}-201 \times \mathrm{PK}) \times$ Rose & AAABB \\
\hline 11 & H 542 & H-02-34 x ANK & $\mathrm{AABB}$ \\
\hline 12 & Н 571 & $\mathrm{H}-04-05$ x Ykm\#5 & $\mathrm{AABB}$ \\
\hline 13 & H 572 & H-03-35 (OP) & $\mathrm{AAB}$ \\
\hline 14 & $\mathrm{H}-573$ & H-03-12 x Rose & AAABB \\
\hline 15 & Н 576 & $\mathrm{H}-201(\mathrm{OP})$ & $\mathrm{AB}$ \\
\hline 16 & Н 589 & H-03-19 (OP) & $\mathrm{AABB}$ \\
\hline \multicolumn{4}{|c|}{ Parents } \\
\hline 1 & PL & Highly Resistance source (Check) & AA \\
\hline 2 & ANK & Resistance source & AA \\
\hline 3 & PK & Resistance source & $\mathrm{ABB}$ \\
\hline 4 & Ykm\#5 & Resistance source & AAA \\
\hline 5 & Mano. & Resistance source & AAA \\
\hline 6 & Rose & Resistance source & AA \\
\hline 7 & Rasthali & Highly Susceptible source(Check) & $\mathrm{AAB}$ \\
\hline
\end{tabular}

ANK - Anaikomban; PL - Pisang Lilin; PK-Peykunnan; Mano- Manoranjitham OP-Open pollinated 
Table.5 Dendrogram of 18 genotypes of Musa species on 6 ISSR primers constructed using UPGMA based on Jaccard's Coefficient

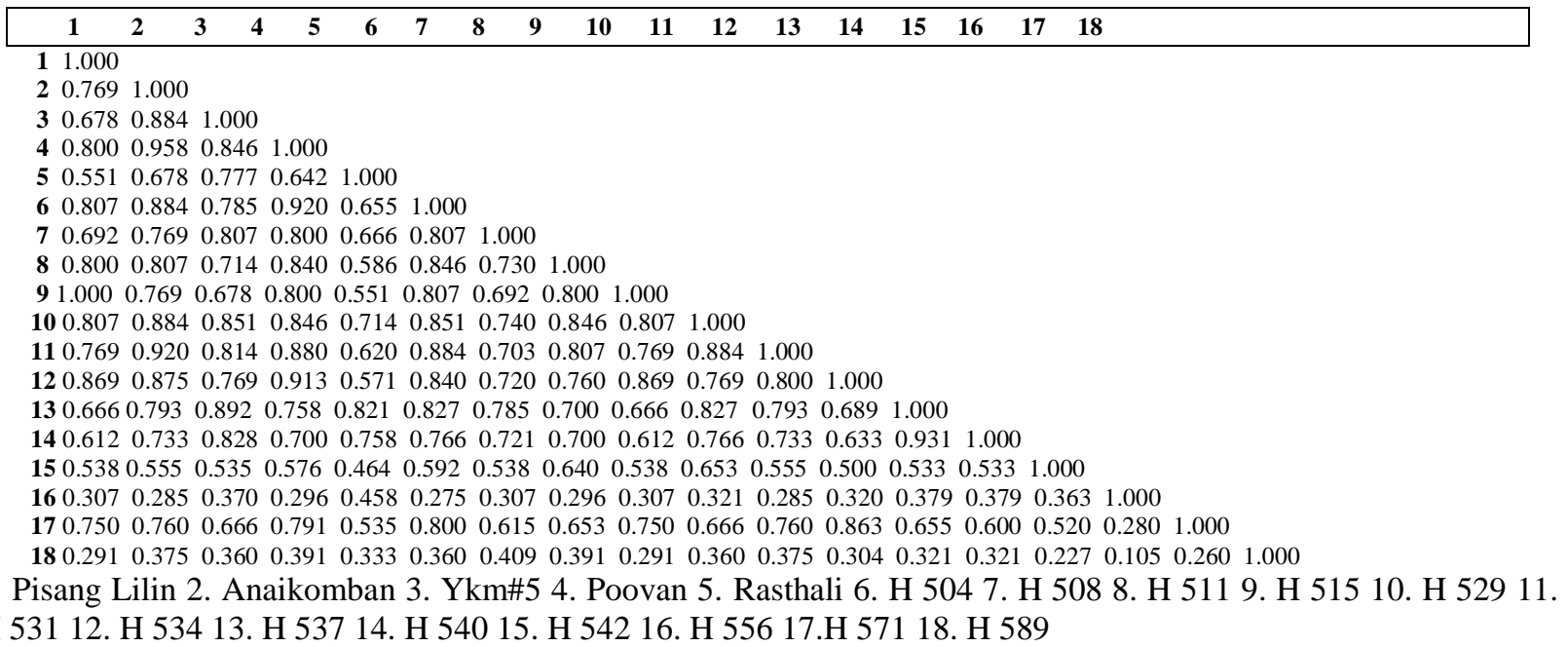

Fig.1 ISSR analysis of phase I banana hybrids using primer UBC 812

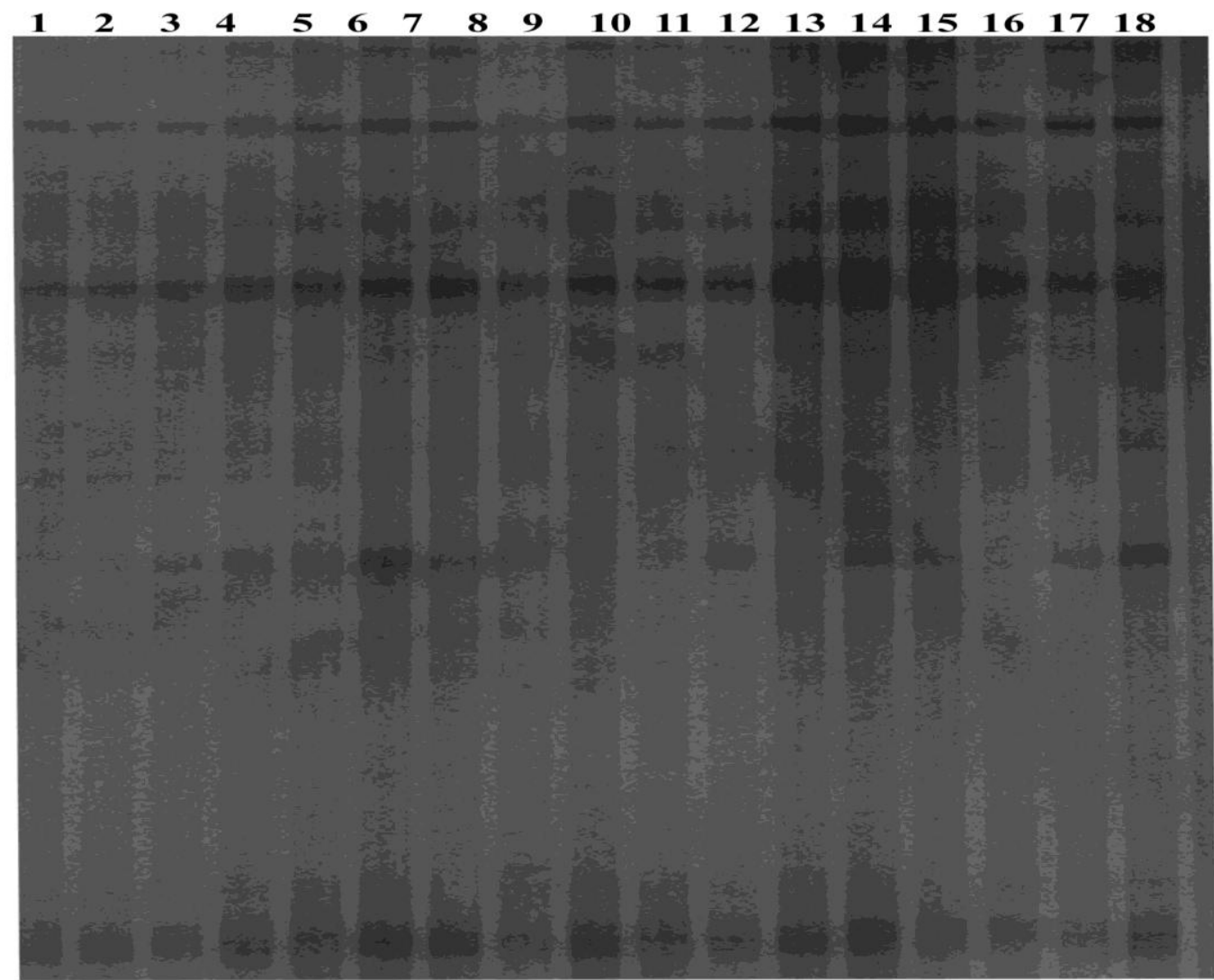

1. Pisang Lilin 2. Anaikomban 3. Ykm\#5 4. Poovan

5. Rasthali 6. H 504 7. H 508 8. H 5119. H 515

10. H 529 11. H 531 12. H 534 13. H 537 14. H 540

15. H 542 16. H $55617 . H 571$ 18. H 589 
Fig.2 ISSR analysis of phase I banana hybrids using primer UBC 812

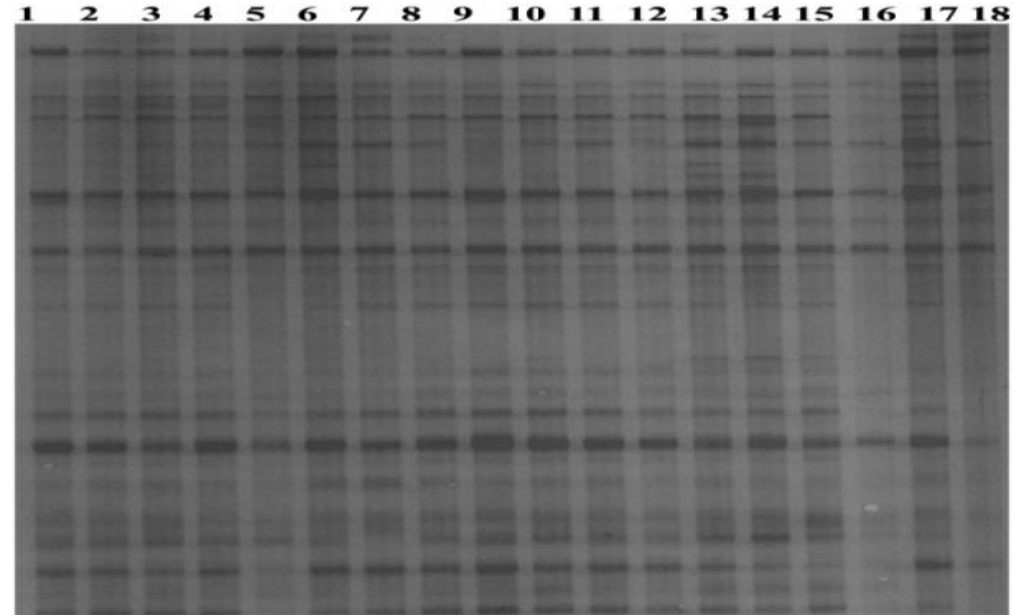

1. Pisang Lilin 2. Anaikomban 3. Ykm\#5 4. Poovan

5. Rasthali 6. H 504 7. H 508 8. H 5119 . H 515

10. H 529 11. H 531 12. H 534 13. H 537 14. H 540

15. H 54216 . H $55617 . H 571$. 1 . H 589

Fig.3 Dendrogram of 18 genotypes of Musa hybrids and referent cultivars on 6 ISSR primers constructed using UPGMA based on Jaccard's coefficient

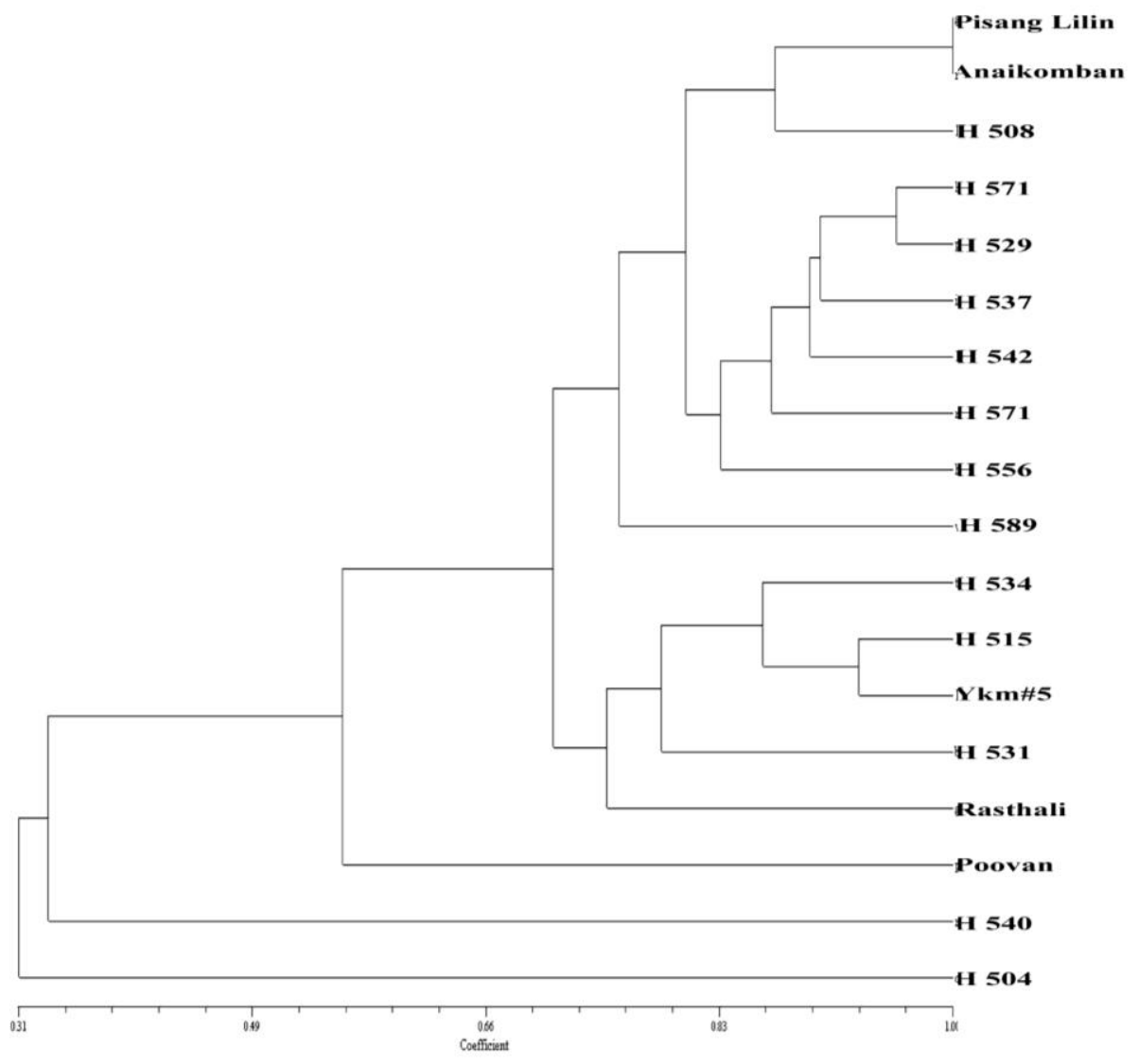


ISSR were employed for molecular assessment of genetic identity and genetic stability in banana cultivars, Lu et al., (2011). Recently, ISSR were used to analyse the pattern of genetic variation and differentiation in 32 individuals along with two reference samples of wild Musa, which corresponded to three populations across the biodiversity-rich hot-spot of the southern Western Ghats of India (Padmesh et al., 2012).

The ISSR profiles indicated that each primer could generate polymorphisms among the accessions. The polymorphism may be due to mutation at priming sites and/or insertion/deletion event within the SSR region; and the extent of polymorphism also varies with the nature and the sequence repeat of the primer used by Reddy et al., (2002). In order to supplement with the results of ISSR analysis was also carried out. To confirm in the present study, ISSR markers were used. Six primers were used to screen 18 hybrids and parents which produced 54 markers with a polymorphism percentage of 53.83. Cluster analysis grouped the accessions into two major clusters (Tables 5 and Fig. 3). A maximum of 18 markers per primer was observed in ISSR, which showed the informative nature of these markers. The average number of markers per primer in ISSR was nine and ISSR markers gave a polymorphism of 53.83 per cent by using just six primers (Table 1 and 2). This shows that even a few ISSR primers are sufficient to provide information needed in diversity analysis, thereby saving resources. ISSRs segregate mostly as dominant markers following simple Mendelian inheritance, Gupta et al., (1994). Out of six primers studied ISSR primer UBC 812 produced maximum number of polymorphic $(100.00 \%)$ bands among the banana genotypes and might be useful for genetic diversity studies. ISSR remain attractive options despite availability of sophisticated techniques because they are easy, quick, simple and economical. Neither sequence information nor any prior genetic studies are required for these analyses.

Based on the results obtained in the present study, it can be concluded that ISSR markers which are independent of environmental conditions and show higher levels of polymorphism can serve as an efficient tool in molecular diversity studies. Assessment of genetic diversity is important for parent selection in crop improvement, management of germplasm and IPR issues, and for ascertaining evolutionary relationships. Thus, in the above study Diversity analysis carried out by using ISSR markers in some banana hybrids revealed the confirmation of the hybridization along with the phylogenetic relationship of the hybrids with their pedigree.

\section{Acknowledgement}

The authors wish to thank and acknowledge the financial support of the Flemish office for Development Cooperation and Technical Assistance (VVOB), Belgium and the International Network for the Improvement of Banana and Plantain (INIBAP) obtained through NRC for banana.

\section{References}

Agoreyo B.O. Golden K.D. and Brown S.E. 2008. Analysis of genetic variability among plantain cultivars (Musa paradisiaca L.) using arbitrarily primed PCR technique. African J Biotech, 7: 1041-1045.

Bhakthavatsalu C.M. and Sathiamoorthy S. 1979. Banana clonal situation in India: A resume. Fruits, 11: 34-46.

Bhat K.V. and Jarret. R. L. 1995. Random amplified polymorphic DNA and genetic diversity in India Musa germplasm. Genetic Resources Crop Evol., 42: 107-118. 
Bhat K.V., Bhat S R. and Chandel K.P.S. 1992. Survey of isozyme polymorphisms and catalase. J. Hort. Sci., 67:501-507.

Bhat K.V. and Jarret R. L and Liu Z.W. 1994. RFLP characterization on Indian Musa germplasm for clonal identification and classification. Euphytica, 80: 95-103.

Brown N., Venkatasamy S., Khittoo G., Bahorun T., Jawaheer S. 2009. Evaluation of genetic diversity between 27 banana cultivars (Musa spp.) in Mauritius using RAPD markers. African J Biotech 8: 1834- 1840.

Crouch H.K., Crouch J.H., Madsen S., Vuylsteke D.R., Ortiz R. 2000. Comparative analysis of phenotypic and genotypic diversity among plantain landraces (Musa spp., AAB group). Theor Appl Genet., 101: 1056-1065.

Crouch J H., Crouch H K., Constandt H., Van Gysel A, Breyne P., Van Montagu M., Jarret R.L. and Ortiz R. 1999. Comparison of PCR-based molecular marker analyses of Musa breeding populations. Mol. Breed., 5:233-244.

Gawel, N. J. and Jarret R. L. 1991. Cytoplasmic genetic diversity in banana and plantain. Euphytica., 52: 19-23.

Godwin I.D., Aitken E.A.B. and Smith L.W. 1997. Application of inter simple sequence repeat (ISSR) Markers to plant genetics. Electrophoresis., 18.1524-1428.

Grajal-Martin M., Siveno-Grillo G. and Marrero- Dominguez A. 1998. The use of randomly amplified polymorphic DNA (RAPD) for the study of genetic diversity and somaclonal variation in Musa. Acta Hort., 490: 445-454.

Grapin A., Noyer J.L., Carreel F., Dambler D., Baurens F.C., Lanaud C. and Lagoda P. J. L.1998. Diploid Musa acuminate genetic diversity assayed with sequence tagged microsatellite sites. Electrophoresis., 19: 1374-1528.
Gupta R.B., Paul J.G., Cornish G.B., Palmer G.A., Bekes F., Rathjen A.J.1994. Allelic variation at glutenin subunit and gliadin loci, Glu-1-Glu-3 and Gli-1 of common wheat. I. Its additive and interaction effects on dough properties. J Cereal Sci. 19: 9-17

Harirah A.A. and Khalid N. 2006. Direct regeneration and RAPD assessment of male inflorescence derived plants of Musa acuminata cv.Berangan. Asia Pacific J Mol Biol Biotech, 1: 11-17.

Howell E. C., Newbury H. J., Swennen R.L., Withers L.A. and Ford Lyod, B.V. 1994. The use of RAPD for identifying and classifying Musa germplasm. Genome., 37:328-332.

Jagannath P. S.K., Kumar N., Soorianathasundaram K. and Maheswaran, M. 2003. P107Molecular characterization of Musa diploids using RAPD markers $1^{\text {st }}$ international Congress on Musa. Harnessing research to improve livelihoods, Penang, Malaysia, 6-9 July, 2004. p.86.

Jain P.K., Saini M.L., Pathak H., Gupta P.K.2007.Analysis of genetic variation in different banana (Musa species) variety using random amplified polymorphic DNAs (RAPDs). African J Biotech, 6: 1987- 1989.

Jarret R L., Gawel N.J., Whittemore A., Sharrock S. 1992. RFLP based phylogeny of Musa species in Papua New Guinea. Theor. Appl. Genet., 84. 579-584.

Jarret R.L. and Gawel N.1995. Molecular markers, genetic diversity and systematics in Musa. In: Gowen S (ed.). Bananas and plantains. Chapman and Hall, London.

Kaemmer D., Afza R., Weising K., Kahl G., Novak F J. 1992. Oligonucleotide and amplification fingerprinting of wild species and cultivar of Banana (Musa 
spp.). Biocontrol.10: 1030-1035.

Kaemmer D., Fischer D., Jarret R.L., Baurens F.C., Grapin A., Dambier D., Noyer J.L., Lanaud C., Kahl G. and Lagoda P.J.L. 1997. Molecular breeding in the genus Musa a strong case for STMS marker technology. Euphytica., 96:4993.

Khatri A., Dahot M.U., Khan I., Raza S., Bibi S., Yasmin S., Nizamani D.G.S. 2011. In vitro mutagenesis in banana and variant screening through ISSR. Pak J Bot; 43(5) 2427-2431.

Lakshmanan V., Venkataramareddy S.R., Neelwarne B.2007. Molecular analysis of genetic stability in long-term micropropagated shoots of banana using RAPD and ISSR markers. Electronic J $\begin{array}{llll}\text { Biotech } & 10 \quad \text { (1) http://www. }\end{array}$ ejbiotechnology.info/content/vol10/ issue 1/full/12.

Loh J. P. Kiew K., Set O., Gan L. H., Gan Y.Y. 2000. Amplified fragment length polymorphism fingerprinting of 16 banana cultivers (Musa cvs.). Mol. Phylogenet. Evol.,17:360-366.

Lu Y., Xu W.H., Xie Y.X., Zhang Z., Pu J.J., Qj Y.X., Li H.P. 2011. Isolation and characterization of nucleotide-binding site and C-terminal leucine-rich repeatresistance gene candidates in bananas. Genet Mol Res, 10(4) 3098-3108.

Lynch M. and Milligan B.G. 1994. Analysis of population genetic structure with RAPD markers. Mol. Ecol., 3: 91-99.

Meenakshisundaram, P. 2002. DNA profiling in Phyllanthus species using RAPD and ISSR markers. M.Sc.(Ag.) thesis. Tamil Nadu Agricultural University, Coimbatore, India.

Onguso J.M., Kahangi E.M., Ndiritu D.W., Mizutani F. 2004. Genetic characterization of cultivated bananas and plaintains in Kenya by RAPD markers. Sci. Horticult., 99: 9-20.
Padmesh P., Mukunthakumar S., Vineesh P.S., Hari Kumar K., Krishnan P.N.2012. Exploring wild genetic resources of Musa acuminata Colla distributed in the humid forests of southern Western Ghats of peninsular India using ISSR markers. Plant Cell Reports, 31(9) 1591-1601.

Panaud O., Chen, X. and McCouch S.R.1996. Development of microsatellite. markers and characterization of simple sequence length polymorphism (SSLP) in rice (Oryza sativa L.). Mol. Gen. Genet., 252, 597-607.

Pillay M, Nwakanma D.C., Tenkouano A. 2000. Identification of RAPD markers linked to $\mathrm{A}$ and $\mathrm{B}$ genome sequences in Musa L. Genome. 43: 763-767.

Powell W., Morgane M., Andre C., Hanafey M., Vogel J., Tingey S.V. and Rafalski A. 1996. The comparison of RFLP, RAPD, AFLP and SSR markers for germplasm analysis. Mol. Breed., 2:225-38.

Qin X.Q., Peng H.X., Long X., Yao J.Y. 2014. Preliminary study on ISSR analysis and classification of wild Musa germplasm in Guangxi, China. Acta Hort; 897: 259-262. http://www.actahort.org/books/897/897 _29.htm.

Racharak P., Eiadthong W. 2007. Genetic relationship among subspecies of Musa acuminata Colla and A-genome consisting edible cultivated bananas assayed with ISSR markers. Songklanakarin J Sci Tech 29: 14791489.

Raman V.S., Sree Rangasamy S. R. and Ali Khan W. M. 1968. Metroglyph analysis of South Indian varieties in banana complex. Ind. J. Bot. Soc., 47:210-18.

Ray T., Dutta I., Saha P., Das S., Roy S.C. 2006. Genetic stability of three economically important micropropagated banana (Musa spp.) 
cultivars of lower Indo-Gangetic plains, as assessed by RAPD and ISSR markers. Plant Cell Tiss Org Cult, 85 (1) $11-21$.

Reddy M.P., Sarla N., Siddiq E.A. 2002. Inter simple sequence repeats (ISSR) polymorphism and its application in plant breeding. Euphytica 128: 9-17.

Rekha. A, Sai Prasad G.V.S., Anand L. and Ravishanker K.V. 2004. The use of RAPD markers to detect variability between $\mathrm{AB}$ cultivers. $1^{\text {st }}$ international Congress on Musa. Harnessing research to improve livelihoods, Penang, Malaysia, 6-9 July, 2004. p.87.

Rohlf F.J.1994. NTYYS-pc Numerical taxonomy and multivariate analysis system. Exeter software, New York.

Rout G.R., Senapati S.K., Aparajita S., Palai S.K. 2009. Studies on genetic identification and genetic fidelity of cultivars banana using ISSR marker. Plant Omics Journal, 2(6): 250-258.

Ruangsuttapha S., Eimert K., Schöder M.B., Silayoi B., Denduangboripant J., Kanchanapoom K. 2007. Molecular phylogeny of banana cultivars from Thailand based on HAT-RAPD markers. Gen Res Crop Evol., 54: 15651572.

Sambrook J., Fritsch E.F. and T. Maniatis.1989. Molecular Cloning -a Laboratory Manual $2^{\text {nd }}$ ed. Cold sring Harbor, New York. P. 167.
Smith J.S.C., Chin, E.C.L., Shu, H., Smith O.S., wall S. J., Senior M.L., Mitchell S.E., Kresovich S. and Ziegle J. 1997. An evaluation of SSR loci as molecular markers in Maize (Zea mays L): Comparison with data from RFLPs and pedigree. Theor. Appl. Genet., 95: 16373.

Tingey S.V., Rafalski J.A., Hanafey M.K.1994. Genetic analysis with RAPD markers. In: Coruzzi C, Puidormenech $\mathrm{P}$ (eds.). Plant molecular biology. Springer, Berlin.

Venkatachalam L., Sreedhar V., Bhagyalakshmi.2007. Genetic analyses of micropropagated and regenerated of banana as assessed by RAPD and ISSR markers. In Vitro Cellular Dev Biol Plant 43: 267-274.

Welsh J. and Mc Clelland M. 1990. Fingerprinting genomes using PCR with arbitrary primers. Nucl Acids Res. 18: 7213-7218.

Williams, J. G. K., Kubelik, A. R., Livak, K. J., Rafalski, J. A. and Tingey S.V. 1990. DNA polymorphisms amplified by arbitrary primers are useful as genetic markers. Nucl. Res., 18: 6531-6535.

Wong C., Kiew R., Loh J. P., Gan L. H, Set O., Lee S. K., Lum S., Gan Y. Y 2001. Genetic diversity of the wild banana Musa acuminate Colla in Malaysia as evidenced by AFLP. Ann. Bot. 88: 1017-1025.

\section{How to cite this article:}

Sukhen Chandra Das, T.N. Balamohan, K. Poornima and Van Den Bergh, I. 2018. Evaluation of Genetic Diversity in Some Banana Hybrids using ISSR Markers. Int.J.Curr.Microbiol.App.Sci. 7(01): 146-157. doi: https://doi.org/10.20546/ijcmas.2018.701.016 